$\begin{array}{ll}\text { Volume } & : 05 \\ \text { Nomor } & : 03 \\ \text { Bulan } & : \text { September } \\ \text { Tahun } & : 2019 \\ \text { http } & : \text { //ejurnal.pps.ung.ac.id/index.php/AKSARA/index }\end{array}$

\title{
MENINGKATKAN HASIL BELAJAR PESERTA DIDIK MELALUI PENERAPAN MODEL PEMBELAJARAN TEMATIK
}

\author{
Emi Kasim \\ SDN 06 MARISA \\ Email: emikasim@gmail.com
}

Received: 02 Juni 2019; Revised: 19 Juli 2019; Accepted: 25 Agustus 2019

\begin{abstract}
ABSTRAK
Penelitian Tindakan Kelas ini dilakukan sebagai upaya menjawab permasalahan yang terjadi dikelas II SDN 06 Marisa Kabupaten Pohuwato. Yaitu pelaksanaan pembelajaran tematik dengan memadukan beberapa mata pelajaran menjadi satu dalam bentuk tema. Tujuan dilakukan penelitian ini adalah untuk meningkatkan hasil belajar peseta didik. Penelitian Tindakan Kelas ini dilaksanakan dalam dua siklus yang pada tiap siklus meliputi empat tahap PTK, yaitu perencanaan, pelaksanaan, pengamatan dan refleksi. Dari hasil penelitian diperoleh bahwa pembelajaran tematik mampu meningkatkan hasil belajar peseta didik kelas II SDN 06 Marisa Tahun Pelajaran 2015-2016. Melalui pembelajaran tematik diperoleh hasil belajar peserta didi pada siklus I sebesar 70,37\% dan meningkat pada siklus II menjadi $88,88 \%$. Hal ini berarti indikator keberhasilan kinerja sebagai ukuran keberhasilan peserta didik dalam proses pembelajaran tercapai.
\end{abstract}

Kata Kunci : Pembeajaran Tematik, Hasil Belajar

\section{PENDAHULUAN}

Tujuan pendidikan pada dasarnya adalah mengantarkan peserta didik menuju perubahan perubahan tingkah laku, baik berupa pengetahuan, sikap, moral maupun sosial agar dapat hidup mandiri sebagai makhluk individu dan dan hidup bermasyarakat dengan baik sebagai makhluk sosial. Untuk mencapai tujuan tersebut, peserta didik berinteraksi dengan lingkungan belajar, dimana pada lingkungan belajar disekolah interaksi ini diatur oleh guru. Karena guru merupakan salah satu faktor utama dalam menentukan mutu pendidikan.

Adapun salah satu model pembelajaran yang dapat membantu guru untuk mengelola proses pembelajaran yang efektif dan dapat memberikan peserta didik ruang bebas untuk mewujudkan potensinya adalah model pembelajaran tematik. Pembelajaran tematik lebih menekankan pada keterlibatan peserta didik dalam proses belajar secara aktif dalam proses pembelajaran, sehingga peserta didik dapat memperoleh pengalaman langsung dan terlatih untuk dapat menemukan sendiri berbagai pengetahuan yang dipelajarinya.

Model pembelajaran ini sebenarnya bukan hal yang baru bagi guru Sekolah Dasar (SD), karena dikurikulum sebelumnya pada kelas rendah seperti kelas satu, dua dan tiga sudah menggunakan model pembelajaran tematik. Dalam model pembelajaran tematik integratif ini, materi ajar tidak disampaikan berdasarkan mata pelajaran tertentu saja, melainkan dalam bentuk tema-tema yang mengintegrasikan seluruh mata pelajaran sehingga dapat memberikan pembelajaran bermakna pada peserta didik

Model pembelajaran tematik ini mengintegrasikan sikap, ketrampilan dan pengetahuan dalam proses pembelajaran. Selain itu juga, sebuah tema mengintegrasikan berbagai konsep dasar yang berkaitan. Peserta didik tidak belajar konsep secara parsial, sehingga memberikan makna yang utuh kepada peserta didik seperti tercermin pada berbagai tema. 


$\begin{array}{ll}\text { Volume } & : 05 \\ \text { Nomor } & : 03 \\ \text { Bulan } & : \text { September } \\ \text { Tahun } & : 2019 \\ \text { http } & : \text { //ejurnal.pps.ung.ac.id/index.php/AKSARA/index }\end{array}$

Oleh karena itu, dalam proses pembelajaran saya bermaksud mengadakan penelitian tindakan kelas di kelas II SDN 06 Marisa dengan judul penelitian adalah "Meningkatkan Hasil Belajar Peserta Didik Kelas II SDN 06 Marisa Melalui Penerapan Model Pembelajaran Tematik Tahun Pelajaran 2015-2016"

\section{TINJAUAN PUSTAKA}

\section{Hasil Belajar}

Hasil belajar seringkali digunakan sebagai ukuran untuk mengetahui seberapa jauh seseorang menguasai bahan yang diajarkan. Hasil belajar berasal dari dua kata yaitu "hasil" dan "belajar". Hasil (product) merupakan suatu perolehan akibat dilakukannya suatu aktivitas atau proses yang mengakibatkan berubahnya input secara fungsional. Sedangkan belajar adalah tahapan perubahan seluruh tingkah laku individu yang relatif menetap sebagai hasil pengalaman dan interaksi dengan lingkungan yang melibatkan proses kognitif. Perubahan tingkah laku dalam hal ini seperti tingkah laku yang diakibatkan oleh proses kematangan fisik, keadaan mabuk, lelah, dan jenuh tidak dipandang sebagai proses belajar.

Sebelum ditarik kesimpulan tentang pengertian hasil belajar, terlebih dahulu dipaparkan beberapa pengertian hasil belajar dari beberapa ahli, diantarannya:

Menurut Nana Syaodih Sukmadinata, hasil belajar merupakan realisasi potensial atau kapasitas yang dimiliki seseorang. penguasaan hasil belajar seseorang dapat dilihat dari prilakunya, baik prilaku dalam bentuk penguasaan pengetahuan, keterampilan berfikir maupun keterampilan motorik.

Menurut Ngalim Purawanto, hasil belajar merupakan kemampuan yang diperoleh individu setelah proses belajar berlangsung, yang dapat memberikan perubahan tingkah laku baik pengetahuan, pemahaman, sikap dan keterampilan peserta didik sehingga menjadi lebih baik dari sebelumnya

Menurut Asep Jihad, hasil belajar adalah perubahan tingkh laku peserta didik secara nyata setelah dilakukan proses belajar mengajar yang sesuai tujuan pembelajaran

Menurut Hamalik, hasil belajar adalah sebagai terjadinya perubahan tingkah laku pada diri seseorang yang dapat diamati dan diukur bentuk pengetahuan, sikap dan keterampilan

Menurut Catharina Tri Anni, hasil belajar, adalah perubahan perilaku uyang diperoleh peserta didik setelah mengalami aktivitas belajar.

Dari uraian definisi-definisi di atas dapat ditarik kesimpulan hasil belajar adalah suatu hasil yang telah dicapai setelah mengalami proses belajar atau setelah mengalai interaksi dengan lingkungannya guna untuk memperoleh ilmu pengetahuan yang akan menimbulkan tingkah laku sesuai dengan tujuan pembelajaran.

\section{Model Pembelajaran Tematik}

Pembelajaran tematik adalah pembelajaran terpadu yang menggunakan tema sebagai sebagai pemersatu materi dalam beberapa mata pelajaran sekaligus dalam satu kali tatap muka. Pembelajaran tematik merupakan pola pembelajaran yang mengintegrasikan pengetahuan, ketrampilan, kreativitas, nilai dan sikap pembelajaran dengan menggunakan tema. Pembelajaran tematik sangat membuka peluang bagi para guru untuk mengembangkan berbagai strategis dan metodologi paling tepat. Pemilihan dan pengembangan strategi pembelajaran mempertimbangkan kesesuaian dengan tema - tema dipilih sebelumnya. Disinilah guru dituntut lebih kreatif dalam menghadirkan suasana pembelajaran yang menggiring peserta didik mampu memahami kenyataan hidup yang dijalaninya setiap hari, baik menyangkut dirinya sebagai pribadi maupun dalam keluarga, masyarakat, lingkungan dan alam sekitarnya 


$\begin{array}{ll}\text { Volume } & : 05 \\ \text { Nomor } & : 03 \\ \text { Bulan } & : \text { September } \\ \text { Tahun } & : 2019 \\ \text { http } & : / / \text { ejurnal.pps.ung.ac.id/index.php/AKSARA/index }\end{array}$

Pembelajaran tematik lebih menekankan pada keterlibatan peserta didik dalam proses belajar secara aktif dalam pembelajaran, sehingga peserta didik dapat memperoleh pengalaman langung dan terlatih untuk dapat menemukan sendiri berbagai pengetahuan yang dipelajarinya. Melalui pengalaman langsung peserta didik akan memahami konsep - konsep yang mereka pelajari dan menghubungkan dengan konsep lain yang telah dipahaminya

Sebagai suatu model pembelajaran di sekolah dasar, pembelajaran tematik memiliki karakteristik sebagai berikut:

- Berpusat pada peserta didik

- Memberikan pengalaman langsung

- Pemisahan mata pelajaran tidak begitu jelas

- Menyajikan konsep dari berbagai mata pelajaran

- Bersifap fleksibel

- Hasil pembelajaran sesuai dengan minat dan kebutuhan peserta didik

- Menggunakan prinsip belajar sambil bermain dan menyenangkan

\section{METODE PENELITIAN}

Subyek dalam penelitian ini adalah peserta didik SDN 06 Marisa yang duduk di kelas I pada tahun ajaran 2015/2016. Jumlah peserta didik kelas I ada 27 peserta didik. Terdiri dari 14 peserta didik laki-laki dan 13 peserta didik perempuan.

Penelitian ini dilakukan di kelas I SDN 06 Marisa Kabupaten Pohuwato. Penulis mengambil lokasi atau tempat ini dengan pertimbangan bekerja pada sekolah tersebut, sehingga memudahkan dalam mencari data, peluang waktu yang luas dan subyek penelitian yang sangat sesuai dengan profesi penulis.

Selanjutnya pelaksanaan penelitian tindakan kelas dilaksanakan melalui tahapan-tahapan, berikut ini.

1). Tahap Persiapan

$\checkmark$ Membuat skenario pembelajaran yang didasarkan pada materi pelajaran

$\checkmark$ Membuat lembar observasi hasil belajar peserta didik

$\checkmark$ Mempersiapkan pertanyaan-pertanyaan dalam bentuk tulisan

$\checkmark$ Menyusun langkah-langkah kegiatan dan jadwal kegiatan

2). Tahapan Tindakan

Pelaksanaan PTK ini dilaksanakan secara kolaboratif dengan guru lainnya. Kegiatan yang dilakukan adalah sebagai berikut:

$\checkmark$ Mempersiapkan segala sesuatu yang diperlukan dalam pelaksanaan kegiatan

$\checkmark$ Menyusun prosedur pelaksanaan, yaitu urutan kegiatan yang dilakukan

$\checkmark$ Melaksanakan pembelajaran dengan menggunakan model pembelajaran tematik

$\checkmark$ Melaksanakan pemantauan dan evaluasi agar tidak terjadi penyimpangan

$\checkmark$ Jika terjadi penyimpangan segera diadakan modifikasi untuk menjamin tercapainya tujuan

3). Tahapan Pemantauan dan Evaluasi

Pemantauan dan evaluasi berlangsung dalam setiap siklus di mana peneliti dibantu oleh anggota tim peneliti untuk mengamati setiap pelaksanaan siklus yang dilakukan. Setiap hasil pemantauan dan evaluasi dibahas pada tahap analisis dan refleksi. Adapun yang menjadi pedoman dalam pelaksanaan pemantauan dan evaluasi sebagai berikut:

$\checkmark$ Semua aspek yang menjadi indikator hasil belajar peserta didik

$\checkmark$ Proses pembelajaran dengan menggunakan model pembelajaran tematik

$\checkmark$ Alat pengumpul data yang telah disiapkan yakni: 


$$
\begin{array}{ll}
\text { Volume } & : 05 \\
\text { Nomor } & : 03 \\
\text { Bulan } & : \text { September } \\
\text { Tahun } & : 2019 \\
\text { http } & : \text { //ejurnal.pps.ung.ac.id/index.php/AKSARA/index }
\end{array}
$$

$\checkmark$ Lembar observasi tentang kegiatan pembelajaran

$\checkmark$ Lembar observasi tentang hasil belajar peserta didik dalam pembelajaran

4). Analisa dan Refleksi

Pada tahap ini kegiatan yang dilakukan adalah menganalisis hasil yang diperoleh pada tahap observasi dan hasilnya digunakan untuk merefleksi diri apakah peserta didik sudah dapat meningkatkan hasil belajarnya. Hasil analisis ini akan digunakan untuk merencanakan tindakan pada siklus selanjutnya.

\section{Teknik Pengambilan Data}

1) Sumber data: sumber data dalam penelitian ini adalah peserta didik dan guru sebagai anggota peneliti

2) Jenis Data: jenis data yang dikumpulkan adalah data kuantitatif dan data kualitatif yang terdiri atas:

$\checkmark$ Data tentang hasil belajar peserta didik

$\checkmark$ Data tentang proses proses pembelajaran dengan menggunakan model pembelajaran tematik

3) Cara Pengambilan Data

$\checkmark$ Data hasil belajar dalam pembelajaran matematika dengan menggunakan pengamatan langsung kepada peserta didik

$\checkmark$ Data tentang proses belajar mengajar dengan menggunakan model pembelajaran tematik melalui observasi dan umpan balik

HASIL PENELITIAN DAN PEMBAHASAN

Hasil pengamatan yang dilakukan peneliti pada kelas II SDN 06 Marisa dapat dilihat pada lembar observasi penilaian proses pembelajaran dan hasil pengamatan awal, sebagaimana nampak pada tabel dibawah ini

Tabel 1 Lembar Pengamatan Proses Pembelajaran

\begin{tabular}{|c|c|c|c|}
\hline Tahap & Indikator & Aspek yang Diamati/di Nilai & Skor \\
\hline Pendahuluan & $\begin{array}{l}\text { Melakukan Aktivitas } \\
\text { Keseharian }\end{array}$ & $\begin{array}{l}\text { 1. Kehadiran guru tepat waktu } \\
\text { 2. Mempersiapkan buku }\end{array}$ & $\begin{array}{l}5 \\
5\end{array}$ \\
\hline $\begin{array}{l}\text { Kegiatan proses } \\
\text { belajar mengajar }\end{array}$ & $\begin{array}{l}\text { Menentukan materi } \\
\text { dan pentingnya } \\
\text { materi }\end{array}$ & $\begin{array}{l}\text { 1.Kejelasan materi yang diberikan guru } \\
\text { 2. Memanfaatkan alat peraga sebaik mungkin } \\
\text { 3.Penguasaan guru terhadap alat peraga } \\
\text { 4.Memberikan tugas kepada peserta didik } \\
\text { 5.Mengarahkan jawaban peserta didik yang } \\
\text { kurang tepat } \\
\text { 6.Cara mengelompokkan peserta didik } \\
\text { 7.Memberikan kesempatan kepada peserta } \\
\text { didik menjawab pertanyaan }\end{array}$ & $\begin{array}{l}5 \\
3 \\
2 \\
2 \\
2 \\
\\
1 \\
2 \\
2\end{array}$ \\
\hline $\begin{array}{l}\text { Reaksi aktivitas } \\
\text { dalam bentuk nilai }\end{array}$ & Melakukan evaluasi & Memeriksa tugas-tugas peserta didik & 3 \\
\hline $\begin{array}{l}\text { Jumlah } \\
\text { Persentase }\end{array}$ & & & $\begin{array}{l}30 \\
60 \%\end{array}$ \\
\hline
\end{tabular}

Berdasarkan tabel 1 nampak bahwa pada kegiatan pendahuluan guru sudah melakukannya dengan baik. Pada kegiatan proses belajar mengajar, dari tujuh komponen terdapat satu komponen yang memperoleh nilai 5, satu komponen memperoleh nilai 3, empat komponen memperoleh nilai 4 dan satu komponen lainnya memperoleh nilai 1 . Pada reaksi aktivitas 


$\begin{array}{ll}\text { Volume } & : 05 \\ \text { Nomor } & : 03 \\ \text { Bulan } & : \text { September } \\ \text { Tahun } & : 2019 \\ \text { http } & : \text { //ejurnal.pps.ung.ac.id/index.php/AKSARA/index }\end{array}$

dalam bentuk nilai satu komponen belum dilaksanakan guru secara maksimal dan memperoleh nilai 3.

Tabel 2 Hasil Pengamatan Awal

\begin{tabular}{|l|l|l|}
\hline Rentang Nilai & Jumlah & Persentase \\
\hline $85-100$ & 8 & 29,63 \\
\hline $65-84$ & 8 & 29,63 \\
\hline $45-64$ & 8 & 29,63 \\
\hline $0-44$ & 3 & 11,11 \\
\hline Jumlah & 27 & 100 \\
\hline $\begin{array}{l}\text { Persentase peserta didik yang memperoleh nilai } \geq 65= \\
59,26 \%\end{array}$ \\
\hline $\begin{array}{l}\text { Persentase peserta didik yang memperoleh nilai } \leq 64= \\
40,74 \%\end{array}$ \\
\hline
\end{tabular}

Berdasarkan tabel 2 di atas nampak bahwa peserta didik yang memperoleh nilai pada rentang $85-100$, pada rentang nilai $65-84$, dan pada rentang nilai 45 - 64 masing - maisng rentang sebanyak 8 orang atau 59,26\%, sedangkan pada rentang nilai $0-44$ sebanyak 3 orang atau $11,11 \%$.

Dari hasil ini diperoleh gambaran tentang hasil belajar peserta didik yang akan diupayakan peningkatannya melalui penggunaan model pembelajaran tematik. Untuk mempersiapkan segala sesuatu yang digunakan dalam pelaksanaan siklus 1, yaitu skenario pembelajaran dan langkah-langkah pembelajaran tematik. Penggunaan model pembelajaran tematik yang diintegrasikan dengan pembelajaran berlangsung di kelas II SDN 06 Marisa yang diikuti oleh anak yang berjumlah 21 orang peserta didik.

\section{Hasil Penelitian Siklus I}

Pada siklus I diperoleh hasil pengamatan seperti nampak pada tabel dibawah ini

Tabel 3 Lembar Pengamatan Proses Pembelajaran Siklus I

\begin{tabular}{|l|l|l|l|}
\hline Tahap & Indikator & Aspek yang Diamati/di Nilai & Skor \\
\hline Pendahuluan & $\begin{array}{l}\text { Melakukan Aktivitas } \\
\text { Keseharian }\end{array}$ & $\begin{array}{l}\text { 1. Kehadiran guru tepat waktu } \\
\text { 2. Mempersiapkan buku }\end{array}$ & 5 \\
\hline $\begin{array}{l}\text { Kegiatan proses belajar } \\
\text { mengajar }\end{array}$ & $\begin{array}{l}\text { Menentukan materi dan } \\
\text { pentingnya materi }\end{array}$ & $\begin{array}{l}\text { 1.Kejelasan materi yang diberikan guru } \\
\text { 2.Memanfaatkan alat peraga sebaik } \\
\text { mungkin } \\
\text { 3.Penguasaan guru terhadap alat peraga } \\
\text { 4.Memberikan tugas kepada peserta } \\
\text { didik } \\
\text { 5.Mengarahkan jawaban peserta didik } \\
\text { yang kurang tepat } \\
\text { 6.Cara mengelompokkan peserta didik } \\
\text { 7.Memberikan kesempatan kepada } \\
\text { peserta didik menjawab pertanyaan }\end{array}$ & 3 \\
& & $\begin{array}{l}\text { Memeriksa tugas-tugas peserta didik } \\
\text { Reaksi aktivitas dalam }\end{array}$ & 3 \\
bentuk nilai & Melakukan evaluasi & 3 \\
\hline $\begin{array}{l}\text { Jumlah } \\
\text { Persentase }\end{array}$ & & & 36 \\
\hline
\end{tabular}

Pada tabel 3 tentang lembar observasi nampak bahwa pada kegiatan pendahuluan guru sudah melakukannya dengan baik. Pada kegiatan proses belajar mengajar, dari tujuh komponen 


$\begin{array}{ll}\text { Volume } & : 05 \\ \text { Nomor } & : 03 \\ \text { Bulan } & : \text { September } \\ \text { Tahun } & : 2019 \\ \text { http } & : / / \text { ejurnal.pps.ung.ac.id/index.php/AKSARA/index }\end{array}$

terdapat lima komponen yang memperoleh nilai 5, dan dua komponen memperoleh nilai 4 . Pada reaksi aktivitas dalam bentuk nilai satu komponen telah dilaksanakan guru secara maksimal dan memperoleh nilai 5. Jumlah seluruh aspek yang telah dijalankan oleh guru sebanyak sepuluh atau $72 \%$

Selanjutnya hasil pengamatan terhadap peserta didik diperoleh bahwa bahwa pada kegiatan pendahuluan, dari 4 komponen yang diamati, satu komponen memperoleh nilai 5, satu komponen nilai 4, dan dua komponen lainnya nilai 3.

Pada kegiatan proses belajar mengajar, dari tujuh komponen terdapat tiga komponen yang memperoleh nilai 4, dan empat komponen lainnya memperoleh nilai 3 dan 2. Pada reaksi aktivitas dalam bentuk nilai, empat komponen memperoleh nilai 4 , dan dua komponen memperoleh nilai 3. Jumlah seluruh aspek yang telah dilaksanakan oleh peserta didik adalah 58 atau $68,24 \%$

Sedangkan hasil belajar peserta didik melalui penggunaan model pembelajaran tematik hasil seperti nampak pada tabel dibawah ini

Tabel 4

Hasil pengamatan siklus I penggunaan model pembelajaran tematik

\begin{tabular}{|l|l|l|}
\hline Rentang Nilai & Jumlah & Persentase \\
\hline $85-100$ & 9 & 33,33 \\
\hline $65-84$ & 10 & 37,04 \\
\hline $45-64$ & 6 & 22,22 \\
\hline $0-44$ & 2 & 7,41 \\
\hline Jumlah & 27 & 100 \\
\hline \multicolumn{2}{|l|}{ Persentase peserta didik yang memperoleh nilai $\geq 65=70,37 \%$} \\
\hline \multicolumn{2}{|l|}{ Persentase peserta didik yang memperoleh nilai $\leq 64=29,63 \%$} \\
\hline
\end{tabular}

Berdasarkan tabel 4 di atas nampak bahwa peserta didik yang memperoleh nilai pada rentang 85 - 100 sebanyak 9 orang atau 33,33\%, pada rentang nilai $65-84$ sebanyak 10 orang atau $37,04 \%$, sedangkan pada rentang nilai $45-64$ sebanyak 6 orang atau 22,22\%, dan pada rentang nilai $0-44$ sebanyak 2 orang atau $7,41 \%$.

Dari hasil yang diperoleh pada siklus I terlihat bahwa telah terjadi peningkatan yang diharapkan, namun peneliti dan kolaborator masih ingin melanjutkan pelaksanaan siklus kedua dengan alasan hasil peroleh yang ditetapkan pada indikator kinerja belum tercapai, selain itu agar pembelajaran ini dapat memberikan gambaran tentang hasil penggunaan model pembelajaran tematik yang digunakan untuk meningkatkan hasil belajar peserta didik.

Peningkatan hasil belajar peserta didik dengan penggunaan model pembelajaran tematik untuk siklus I, sebagai berikut:

$\checkmark$ Sebagian peserta didik sudah siap dalam belajar

$\checkmark \quad$ Sebagian peserta didik sudah mampu menyimak penjelasan guru

$\checkmark$ Sebagian peserta didik sudah mampu berinteraksi dengan guru

$\checkmark \quad$ Sebagian peserta didik sudah mampu mengerjakan tugas dengan baik dan benar

Dari hasil refleksi, terungkap bahwa masih ada yang perlu ditingkatkan dari cara guru melaksanakan model pembelajaran tematik, yaitu:

$\leftrightarrow$ Guru mengalami kesulitan untuk menentukan jenis hadiah yang diberikan kepada peserta didik

$\leftrightarrow$ Guru perlu menyediakan sarana pembelajaran yang lebih baik

Berdasarkan hal tersebut di atas, maka dirasa perlu untuk melaksanakan siklus kedua. 


$\begin{array}{ll}\text { Volume } & : 05 \\ \text { Nomor } & : 03 \\ \text { Bulan } & : \text { September } \\ \text { Tahun } & : 2019 \\ \text { http } & : \text { //ejurnal.pps.ung.ac.id/index.php/AKSARA/index }\end{array}$

\section{Hasil penelitian siklus II}

Kegiatan pengamatan pada siklus II masih sama dengan pengamatan yang dilaksanakan pada siklus I. Motivasi pada kegiatan awal dilakukan dengan memberikan dorongan kepada peserta didik agar dapat memperhatikan penjelasan materi pelajaran. Dorongan yang diberikan oleh guru di antaranya menyangkut pentingnya materi tersebut dipelajari oleh peserta didik karena berkaitan langsung dengan kegiatan pada kehidupan sehari-hari. Hasil pengamatan siklus II seperti nampak pada tabel dibawah ini

Tabel 5 Lembar Pengamatan Proses Pembelajaran

\begin{tabular}{|c|c|c|c|}
\hline Tahap & Indikator & Aspek yang Diamati/di Nilai & Skor \\
\hline Pendahuluan & $\begin{array}{l}\text { Melakukan Aktivitas } \\
\text { Keseharian }\end{array}$ & $\begin{array}{l}\text { 1. Kehadiran guru tepat waktu } \\
\text { 2. Mempersiapkan buku }\end{array}$ & $\begin{array}{l}5 \\
5\end{array}$ \\
\hline $\begin{array}{l}\text { Kegiatan proses } \\
\text { belajar mengajar }\end{array}$ & $\begin{array}{l}\text { Menentukan materi } \\
\text { dan pentingnya materi }\end{array}$ & $\begin{array}{l}\text { 1.Kejelasan materi yang diberikan } \\
\text { guru } \\
\text { 2.Memanfaatkan alat peraga sebaik } \\
\text { mungkin } \\
\text { 3.Penguasaan guru terhadap alat } \\
\text { peraga } \\
\text { 4.Memberikan tugas kepada } \\
\text { peserta didik } \\
\text { 5.Mengarahkan jawaban peserta } \\
\text { didik yang kurang tepat } \\
\text { 6.Cara mengelompokkan peserta } \\
\text { didik } \\
\text { 7.Memberikan kesempatan kepada } \\
\text { peserta didik menjawab pertanyaan }\end{array}$ & $\begin{array}{l}5 \\
5 \\
4 \\
5 \\
4 \\
5 \\
5\end{array}$ \\
\hline $\begin{array}{l}\text { Reaksi aktivitas dalam } \\
\text { bentuk nilai }\end{array}$ & Melakukan evaluasi & $\begin{array}{l}\text { Memeriksa tugas-tugas peserta } \\
\text { didik }\end{array}$ & 5 \\
\hline \multicolumn{3}{|l|}{$\begin{array}{l}\text { Jumlah } \\
\text { Persentase }\end{array}$} & $\begin{array}{l}48 \\
96 \%\end{array}$ \\
\hline
\end{tabular}

Pada tabel 5 dapat dilihat kegiatan pembelajaran yang dilaksanakan guru telah mencakup keseluruhan aspek dan telah dimaksimalkan pelaksanannnya. Sedangkan kegiatan peserta didik sudah dapat ditingkatkan guru dalam proses pembelajaran.Sedangkan hasil belajar peserta didik dapat dilihat pada tabel dibawah ini

Tabel 6 Hasil pengamatan siklus II penggunaan model pembelajaran tematik

\begin{tabular}{|l|l|l|}
\hline Rentang Nilai & Jumlah & Persentase \\
\hline $85-100$ & 12 & 44,44 \\
\hline $65-84$ & 12 & 44,44 \\
\hline $45-64$ & 2 & 7,41 \\
\hline $0-44$ & 1 & 3,71 \\
\hline Jumlah & 27 & 100 \\
\hline \multicolumn{2}{|l|}{ Persentase peserta didik yang memperoleh nilai $\geq 65=88,88 \%$} \\
\hline \multicolumn{2}{|l|}{ Persentase peserta didik yang memperoleh nilai $\leq 64=11,12 \%$} \\
\hline
\end{tabular}

\section{Pembahasan}




$\begin{array}{ll}\text { Volume } & : 05 \\ \text { Nomor } & : 03 \\ \text { Bulan } & : \text { September } \\ \text { Tahun } & : 2019 \\ \text { http } & : \text { //ejurnal.pps.ung.ac.id/index.php/AKSARA/index }\end{array}$

Berdasarkan jurnal pengamatan dan refleksi bersama maka pada observasi awal diperoleh data sekaligus kelemahan-kelemahan sebagai berikut: (1) guru tidak memberikan pre test sebelum menyajikan pelayaran, (2) guru belum menggunakan model pembelajaran tematik dengan baik, (3) guru belum memberikan kesempatan kepada peserta didik untuk mengajukan pertanyaan-pertanyaan sehubungan dengan materi pembelajaran, (4) penguasaan kelas masih didominasi oleh guru. Hal ini membuat peneliti untuk melaksanakan siklus pertama yang strategi pembelajaran telah didesain sesuai dengan penggunaan model pembelajaran tematik.

Langkah-langkah pembelajarannya adalah sebagai berikut: (1) sebelum melakukan kegiatan ini pembelajaran, maka terlebih dahulu guru memberikan tanya jawab tentang materi pelajaran kepada peserta didik dengan menjelaskan tujuan dan manfaat kegiatan ini, (2) guru memberi kesempatan kepada peserta didik untuk saling bertanya dan berdiskusi serta mengajukan pertanyaan-pertanyaan sesuai dengan materi pelajaran, (3) pada kegiatan pendahuluan penyajian materi dilaksanakan pre test untuk mengetahui pengetahuan dasar/awal peserta didik tentang materi yang disajikan, (4) guru menyampaikan materi pembelajaran atau permasalahan kepada peserta didik sesuai kompetensi dasar yang akan dicapai, (5) guru memberikan kuis secara individual kepada peserta didik untuk mendapatkan skor dasar atau awal, (6) guru memberikan tugas kepada peserta didik, (8) guru mengawasi pelaksanaan kegiatan yang dilakukan oleh peserta didik, sekaligus memberikan petunjuk, (9) guru memfasilitasi peserta didik dalam membuat rangkuman, mengarahkan dan memberikan penegasan pada reaksi aktivitas dalam bentuk nilai. Dari kegiatan pembelajaran tersebut maka pada siklus I terjadi peningkatan hasil belajar peserta didik sebesar 70,37\% atau 19 orang sedangkan 8 orang lainnya memperoleh di bawah 64. Namun demikian pada kegiatan pembelajaran pada siklus I, terdapat kelemahan-kelemahan seperti: peserta didik belum memperhatikan dengan baik setiap penjelasan yang disampaikan oleh guru, guru perlu memberikan hadiah yang lebih menarik peserta didik untuk mengembangkan hasil belajarnya, dan hasil belajar peserta didik belum meningkat sesuai yang diharapkan.

\section{PENUTUP}

Berdasarkan uraian pada pembahasan, maka dapat disimpulkan bahwa telah tercapai peningkatan hasil belajar peserta didik sebesar $80 \%$ melalui penggunaan model pembelajaran tematik sesuai dengan indikator kinerja yang diinginkan. Pada siklus pertama penggunaan model pembelajaran tematik digunakan untuk meningkatkan hasil belajar peserta didik dan terjadi peningkatan hasil belajar peserta didik sebesar 70,37\% Pada siklus II peningkatan hasil belajar peserta didik menjadi $88,88 \%$. Dengan demikian hipotesis yang berbunyi: " Hasil belajar peserta didik kelas II SDN 06 Marisa dapat meningkat jika dalam pembelajaran menggunakan model pembelajaran tematik" teruji kebenarannya.

\section{DAFTAR PUSTAKA}

Asep, Jihad.2009. Evaluasi Pembelajaran. Yogyakarta: Multi Pressindo

Catharina Tri Anni. 2004. Psikologi Belajar . Semarang: IKIP Semarang Press.

Hadi, Sutrisno, 1982. Metode Penelitian. Jakarta: Balai Pustaka

Hajar, Ibnu, 1999. Penelitian Kuantitatif dan Kualitatif. Jakarta: Rineka Cipta

Hakim, Thursan. 2000. Belajar Mengajar Matematika. Jakarta : Depdikbud

Hasibuan dan Moejiono, 2000. Proses Belajar Mengajar. Bandung: Rosdakarya

Nana Syaodih Sukmadinata. 2005. Landasan Psikologi Proses Pendidikan. Bandung: PT Remaja Rosda Karya 